\title{
Unexpected Desaturation with Occlusion Due to Biting in a Deformed Endotracheal Tube in an Intensive Care Patient
}

\author{
Mustafa Ozgur \\ Antakya State Hospital Department of Anesthesiology and Reanimation, Antakya-Hatay/Turkey
}

Key Words: Biting, endotracheal tube

To the Editor,

Patients in intensive care units may need endotracheal tube (ETT) changes for various reasons. For example, a 35-year-old intubated male patient was admitted to our intensive care unit with isolated gunshot wounds to the chest and multiple upper extremity fractures. He was intubated with an $8.5 \mathrm{~mm}$ single-lumen ETT (Bicakcilar, Istanbul, Turkey). Weaning from mechanic ventilation was planned for the fifth day of admission. The patient was not sedated, and the Ramsey sedation score was 3. After the patient became agitated, he was sedated with midazolam. A sudden desaturation occurred, and a leak was found in the patient's tube, which we then replaced with a reinforced tube. When we examined the original tube, we found damage consisting of a hole near $20 \mathrm{~cm}$ of the tube (Figure1).

In the literature, it is reported that ETTs can be easily damaged $(1,2)$. The biting of ETT in nonsedated patients is a potential problem and can lead to complications if not recognized early. To prevent biting of the ETT, many experts advise using devices such as oropharyngeal airways and oral bite blocks (3). However, these are difficult to use in intensive care environments and have some disadvantages, such as the occurrence of pressure ulcers in the mouth. Therefore, anesthetists must be alert to the possibility of unexpected desaturation caused by damaged and deformed tubes when planning to wean a patient from mechanic ventilation.

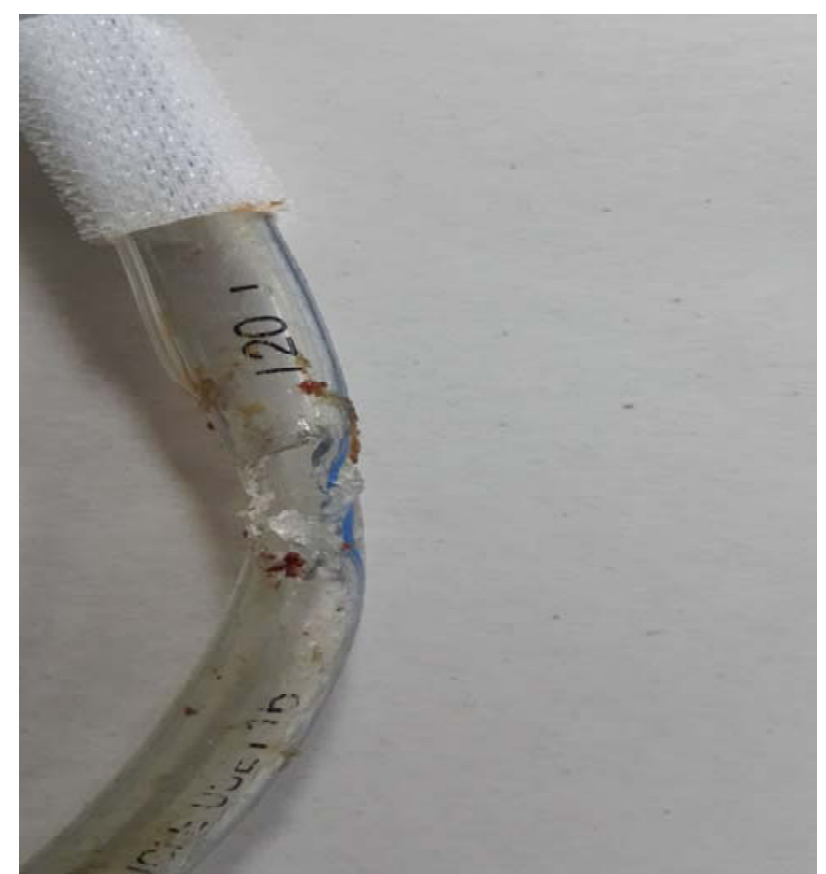

Fig. 1. Damage to the endotracheal tube, caused by biting.

\section{References}

1. Kandasamy R, Sivalingam P. Endotracheal tube damage in the presence of bite block. Anesthesiology 1999; 90(2):637.

2. Tunalı Y, Utku T, Dilmen OK, Akçıl EF. Entübasyon tüpü disseksiyonuna bağl1 akut hava yolu tıkanması. Türk Anest Rean Der Dergisi 2012; 40(3):158-162.

3. Kwan KM, Kok P, Koay CK. Prevention of tube occlusion caused by biting: oral bite block versus oropharyngeal airway. Anaesth Intensive Care 2000; 28(2):227. 